\title{
Refractory Liposarcoma
}

National Cancer Institute

\section{Source}

National Cancer Institute. Refractory Liposarcoma. NCI Thesaurus. Code C150594.

Liposarcoma that does not respond to treatment. 